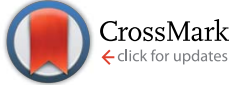

Cite this: RSC Adv., 2016, 6, 101888

\title{
Utilization of a new gold/Schiff-base iron(III) complex composite as a highly sensitive voltammetric sensor for determination of epinephrine in the presence of ascorbic acid $\dagger$
}

\author{
Adam Gorczyński, Maciej Kubicki, Klaudia Szymkowiak, Teresa Łuczak* \\ and Violetta Patroniak*
}

The preparation of new materials that can act as systems capable of sensing biologically relevant molecules constitutes a significant modern challenge as well as a necessity oriented towards disease prevention. Subcomponent self-assembly of 2-(methylhydrazino)benzimidazole, 4-tert-butyl-2,6-diformylphenol and $\mathrm{Fe}\left(\mathrm{ClO}_{4}\right)_{2}\left(\mathrm{H}_{2} \mathrm{O}\right)_{6}$ leads to a new, bimetallic iron(III) complex of the following formula: $\left[\mathrm{Fe}_{2}\left(\mathrm{H}_{3} \mathrm{~L}\right)_{2}(\mathrm{MeOH})_{2}(\mu-\mathrm{OMe})_{2}\right]\left(\mathrm{ClO}_{4}\right)_{4}(1)$, as established by ESI-MS, FTIR and single crystal X-ray analysis. It is important to note that ligand $\mathrm{H}_{3} \mathrm{~L}$ was also successfully synthesized and characterized for the first time. Compound 1 was successfully deposited on a gold electrode and applied as a voltammetric sensor with respect to epinephrine (EP). Cyclic voltammograms (CVs) proved the catalytic activity of the new, electrochemically prepared composite Au/1 for the oxidation of EP in the presence of ascorbic acid (AA). The respective current peaks were clearly separated from each other, thus enabling selective detection of these compounds coexisting in a mixture. For the prepared sensor a linear relationship between the current response of EP electrooxidation at the potential of peak maximum $\left(i_{p}\right)$ and the concentration of $\mathrm{EP}$ in solution $\left(C_{\mathrm{EP}}\right)$ in the presence of constant AA concentration was found in the broad range of $C_{\mathrm{EP}}\left(R^{2}\right.$ $\geq 0.9997,1.0 \times 10^{-8} \mathrm{M}$ to $\left.9.0 \times 10^{-4} \mathrm{M}\right)$ with a high detection limit $\left(7.4 \times 10^{-9} \mathrm{M}\right)$, excellent reproducibility as well as high stability.

Received 2nd September 2016 Accepted 18th October 2016

DOI: $10.1039 / c 6 r a 22028 b$

www.rsc.org/advances into polymer, which makes a serious problem when epinephrine is oxidized directly at the bare electrode due to poisoning and blocking of the electrode surfaces. Another problem is that epinephrine exists in natural environments together with small biomolecules like ascorbic acid, which oxidizes at bare electrodes in almost the same potential region. ${ }^{4,5}$ It is thus necessary to separate the oxidation potentials of these compounds to enable accurate determination of epinephrine. Among various attempts to overcome the above mentioned problems, much attention has been paid to application of chemically or electrochemically modified electrode surfaces. The most papers have been concerned with the voltammetric behavior of bare carbon, carbon fiber and glassy carbon based electrodes. For example a pyrolytic graphite electrode modified with carbon nanotubes, ${ }^{6-8}$ a graphite/mesoporous Al-containing $\mathrm{SiO}_{2}$ electrode, ${ }^{9}$ carbon fiber electrodes covered with overoxidized polypyrrole and $\mathrm{DNA}^{10}$ as well as carbon surface with deposited gold nanoparticles (Au-NPs) ${ }^{11-13}$ have been tested for selective detection of EP in the presence of interfering compounds. Moreover, glassy carbon electrodes modified with an overoxidized polypyrrole ${ }^{14}$ or dopamine, ${ }^{15}$ polycaffeic acid, ${ }^{16}$ luminal, ${ }^{17} \mathrm{Zn}$-Al hydroxide, ${ }^{18}$ 5-amino-1,3,4-thiadiazole-2-thiol ${ }^{19}$ and poly rutin ${ }^{20}$ films were reported. A glassy carbon electrode 


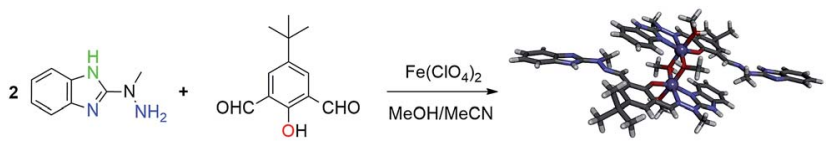

Fig. 1 Schematic formation of new Fe(III) bimetallic complex via subcomponent self-assembly approach.

covered with self-assembled monolayers (SAMs) of cysteamine ${ }^{21}$ as well as with osmium and cobalt hexacyanoferrate, hexacyanoruthenate or phtalocyanine complexes ${ }^{\mathbf{8 , 2 2 - 2 5}}$ have been prepared and investigated upon the electrooxidation of EP. Aside from different carbon materials used as a template for preparing modified electrodes, a promotion of electron transfer in the electrochemical reaction during EP electrooxidation was achieved after application of gold electrodes covered with spontaneously formed SAMs of alkanetiols or other Scontaining organic compounds. ${ }^{26-33}$ It has been proven that the latter electrodes effectively protect the metal surface against adsorption of reaction products that are poisonous for the electrode surface.

As a consequence of facile and efficient synthetic protocols, we have recently focused our attention on Schiff-base scaffolded metallosupramolecular architectures, which renders them suitable systems for viable industrial applications. ${ }^{34-36}$ As a result, novel voltammetric sensor has been developed ( $\mathrm{Au} /$ $\left[\mathrm{Mn}_{2}\left(\mathrm{H}_{2} \mathbf{L}\right)_{2}\right]\left(\mathrm{ClO}_{4}\right)_{2}$ composite, where $\mathrm{H}_{3} \mathbf{L}$ is ligand - 2,6-bis $((2-$ (1H-benzo[d]imidazol-2-yl)-2-methylhydrazono)methyl)-4-(tertbutyl)phenol) and applied for quantitative detection of dopamine and its interfering biogenic compounds. ${ }^{36}$ It has struck us that such systems have been recognized as an unexplored niche with regard to deposition onto gold electrodes and sensing of biologically relevant compounds and in turn inspired us to pursue this subject with regard to the other metal ions. ${ }^{37}$

Despite that a lot of experimental data mentioned above is present, development of novel and easy to synthesize materials capable of simultaneous detection of neurotransmitters in the presence of biogenic molecules, such as AA, is still a challenging task for electrochemists. Motivated by successful application of hardly explored Schiff-base metallosupramolecular architectures as sensors, ${ }^{36}$ we have prepared new bimetallic $\mathrm{Fe}(\mathrm{III})$ complex - $\left[\mathrm{Fe}_{2}\left(\mathrm{H}_{3} \mathbf{L}\right)_{2}(\mathrm{MeOH})_{2}(\mu-\mathrm{OMe})_{2}\right]\left(\mathrm{ClO}_{4}\right)_{4}$ (1) (Fig. 1) successfully deposited it at gold template and evaluated prepared material as electrochemical sensor of EP in the presence of interfering AA.

\section{Experimental}

\subsection{Reagents and physical measurements}

All chemicals were of analytical grade and used as received without further purification: tetrabutylammonium perchlorate $\left(\mathrm{TBAClO}_{4}\right)$, lithium perchlorate $\left(\mathrm{LiClO}_{4}\right), \mathrm{NaH}_{2} \mathrm{PO}_{4}, \mathrm{~K}_{2} \mathrm{HPO}_{4}$, $\mathrm{NaOH}$ and acetonitrile (ACN) from Merck, epinephrine (EP) from Fluka; L-ascorbic acid (AA) and $\mathrm{Fe}\left(\mathrm{ClO}_{4}\right)_{2}\left(\mathrm{H}_{2} \mathrm{O}\right)_{6}$ from Sigma; $\mathrm{H}_{2} \mathrm{SO}_{4}, \mathrm{H}_{2} \mathrm{O}_{2}, \mathrm{EtOH}_{\mathrm{abs}}$, $\mathrm{MeOH}_{\mathrm{abs}}$ from POCh (Gliwice, Poland). All synthetic manipulations were performed under aerobic conditions using solvents and chemicals as received unless otherwise stated.

\subsection{Instrumentation}

Microanalysis of ligand $\mathrm{H}_{3} \mathbf{L}$ as well as bimetallic Fe(III) complex 1 was performed using a Perkin-Elmer 2400 CHN microanalyser. IR spectrum of 1 was obtained with a Perkin-Elmer 580 spectrophotometer and peak positions are reported in $\mathrm{cm}^{-1}$. ESI mass spectra of ligand and 1 were determined in methanolic solution with $c=\sim 10^{-4} \mathrm{M}$ using a Waters Micromass ZQ spectrometer. The electrochemical measurements were carried out in a conventional three-compartment cell separated by glass frits using an Autolab potentiostat/galvanostat analyzer (AUTOLAB PGSTAT 302N, Eco Chemie, B. V., Utrecht, The Netherlands). The scanning electron microscopy (SEM) analysis was carried out using ZEISS EVO 40 instrument (Germany) with the acceleration voltage of $20 \mathrm{kV}$. The transmission electron microscopy (TEM) image was obtained using JEM-1200 EX2 (Japan) instrument, operating at $80 \mathrm{kV}$, after drying the gold colloidal Fe-complex solution covered with the foil strengthened with carbon.

\subsection{Synthesis of ligand $\mathrm{H}_{3} \mathrm{~L}$}

Synthesis of new Schiff-base ligand $\mathrm{H}_{3} \mathrm{~L}$ was performed under nitrogen to eliminate the detrimental effect of moisture on the condensation efficiency. 2-(1-Methylhydrazinyl)-1 $H$-benzo[ $d]$ imidazole $(56.0 \mathrm{mg}, \quad 0.347 \mathrm{mmol})^{36}$ and 4-tert-butyl-2,6diformylphenol (43.2 $\mathrm{mg}, 0.17 \mathrm{mmol}$ ) were transferred to twonecked round bottom flask equipped with the reflux condenser that was previously flushed with inert gas. $10 \mathrm{ml}$ of absolute ethanol was added via syringe and the mixture was stirred on magnetic stirrer, resulting in formation of transparent yellow solution. The mixture was heated for a few hours under reflux what followed precipitation of yellow solid. The content was cooled to room temperature, left to stir overnight and the precipitate was subsequently filtered and washed well with ethyl alcohol and diethyl ether respectively. Recrystallization from DMSO/water system resulted in microcrystalline yellow solid that was dried under vacuum in $50{ }^{\circ} \mathrm{C}$. Yield: $73.15 \mathrm{mg}(87.0 \%)$.

${ }^{1} \mathrm{H}$ NMR (500 MHz, d $\mathrm{d}_{6}$-DMSO): $\delta=1.42(\mathrm{~s}, 9 \mathrm{H}), 3.71(\mathrm{~s}, 6 \mathrm{H})$, 7.00-7.06 (m, 4H), 7.35-7.37 (m, 4H), $7.90(\mathrm{~s}, 2 \mathrm{H}), 8.21(\mathrm{~s}, 2 \mathrm{H})$, 10.53 (s, 1H), 11.79 (s, 2H) ppm. ${ }^{13} \mathrm{C}$ NMR (125 MHz, d 6 -DMSO): $\delta=31.4$, 31.8, 34.1, 109.9, 116.1, 119.7, 120.4, 120.7, 125.6, 134.1, 136.5, 142.0, 142.6, 151.8, 153.4 ppm; elemental analysis calc. for $\left[\mathrm{C}_{28} \mathrm{H}_{30} \mathrm{~N}_{8} \mathrm{O}\right]$ (494.59): C, 68.00; H, 6.11; N, 22.66; found: C, 66.09; H, 6.21; N, 22.61\%. ESI-MS(+) m/z: $495\left[\left(\mathrm{H}_{4} \mathbf{L}\right)\right]^{+}, 517$ $\left[\mathrm{H}_{3} \mathbf{L}+\mathrm{Na}^{+}\right]^{+}, 533\left[\mathrm{H}_{3} \mathbf{L}+\mathrm{K}^{+}\right]^{+}$. Selected IR $\left(\mathrm{KBr}, \mathrm{cm}^{-1}\right): \nu(\mathrm{O}-\mathrm{H})$ $3637(\mathrm{w}), \nu(\mathrm{N}-\mathrm{H}) 3500-2200(\max$. at 3158$)(\mathrm{m} \mathrm{br}) ; \nu(\mathrm{C}-\mathrm{H})_{\mathrm{ar}}$ 3085(m), 3055(m); $\nu_{\mathrm{as}}\left(\mathrm{CH}_{3}\right) 2962(\mathrm{~m}), \nu_{\mathrm{as}}\left(\mathrm{CH}_{3}\right)$ 2929(m); $v_{\mathrm{s}}\left(\mathrm{CH}_{3}\right)$ $2905(\mathrm{w}), \quad 2868(\mathrm{w}) ; \quad \nu(\mathrm{C}=\mathrm{C})_{\mathrm{ar}}, \quad \nu(\mathrm{C}=\mathrm{N}) \quad 1626(v s),. \quad 1597(v s$.$) ,$ 1561(vs.), 1480 (s), 1461(s), 1448(s), 1414(m), 1385(m), 1353(w), $1317(\mathrm{~m}), 1280(\mathrm{~m}), 1224(\mathrm{~m}), \nu(\mathrm{C}-\mathrm{O}) 1264(\mathrm{~m}) ; \gamma(\mathrm{C}-\mathrm{H})_{\mathrm{ar}}, \rho(\mathrm{C}-\mathrm{H})_{\mathrm{ar}}$ 1211(s), 1156(m), 1044(m), 1005(m), 945(s), 821(w), 743(s), 699(w), 677(w), 533(w), 433(w). 
Crystals suitable for X-ray diffraction were obtained from acidified solution of $\mathrm{MeOH} /$ toluene at lowered temperature.

\subsection{Synthesis of iron(III) complex}

Bimetallic iron(III) complex 1 was synthesized in two different ways: method A (similar manner to the recently published one-pot template reaction ${ }^{36}$ with some notable changes), method B (direct complexation with ligand $\mathrm{H}_{3} \mathbf{L}$ ).

2.4.1. Method A. 2-(1-Methylhydrazinyl)-1H-benzo[d]imidazole $(52.3 \mathrm{mg}, 0.324 \mathrm{mmol})$ and 4-tert-butyl-2,6-diformylphenol ( $40.4 \mathrm{mg}, 0.162 \mathrm{mmol}$ ) were placed in $50 \mathrm{ml}$ round bottom flask, dissolved upon addition of $20 \mathrm{ml}$ of $\mathrm{MeOH}$ and stirred for $1 \mathrm{~h}$. Yellow precipitate of formed ligand $\mathrm{H}_{3} \mathbf{L}$ was observed and without isolation transferred to $15 \mathrm{ml}$ of $\mathrm{MeCN} / \mathrm{MeOH}(1: 1 \mathrm{v} / \mathrm{v})$ solution of $\mathrm{Fe}\left(\mathrm{ClO}_{4}\right)_{2}\left(\mathrm{H}_{2} \mathrm{O}\right)_{6}(58.8 \mathrm{mg}, 0.162 \mathrm{mmol})$, what resulted in formation of black solution. Such system was stirred for $48 \mathrm{~h}$ at room temperature without sealing, providing direct access of air. The reaction mixture was subsequently concentrated in vacuo, precipitated with diethyl ether, and recrystallized from $\mathrm{MeOH} / \mathrm{Et}_{2} \mathrm{O}$ at lowered temperature. Single crystal suitable for X-ray analysis was obtained by means of vial-to-vial diffusion at $4{ }^{\circ} \mathrm{C}$ from $\mathrm{MeOH} / \mathrm{iPr}_{2} \mathrm{O}$ system. (cf. crystallographic data). $\left[\mathrm{Fe}_{2}\left(\mathrm{H}_{3} \mathbf{L}\right)_{2}(\mathrm{MeOH})_{2}(\mu-\mathrm{OMe})_{2}\right]\left(\mathrm{ClO}_{4}\right)_{4}$ (1): yield: $85.4 \mathrm{mg}$, $61.1 \%$. Elemental analysis calc. for $\left[\mathrm{C}_{60} \mathrm{H}_{86} \mathrm{Cl}_{4} \mathrm{Fe}_{2} \mathrm{~N}_{16} \mathrm{O}_{28}\right]$ (1) (1624.85): C, 44.35; H, 4.59; N, 13.79; found: C, 44.13; H, 4.73; N, 13.73\%. ESI-MS(+) m/z (\%): 548 (100) $[\mathrm{Fe}(\mathrm{HL})]^{+}, 1095$ (10) $\left[\mathrm{Fe}_{2}(\mathrm{HL})_{2}-\mathrm{H}^{+}\right]^{+}, 1127(<5)\left[\mathrm{Fe}_{2}(\mathrm{HL})_{2}-\mathrm{H}^{+}+(\mathrm{MeOH})\right]^{+}, 1195(<5)$ $\left\{\left[\mathrm{Fe}_{2}(\mathrm{HL})_{2}\right]\left(\mathrm{ClO}_{4}\right)\right\}^{+}$. Selected IR $\left(\mathrm{KBr}, \mathrm{cm}^{-1}\right): \nu(\mathrm{O}-\mathrm{H}) 3700-2200$ (m, br), $\nu(\mathrm{O}-\mathrm{H}) 3638(\mathrm{w}), \nu(\mathrm{N}-\mathrm{H}) 3352(\mathrm{~m}) ; \nu(\mathrm{C}-\mathrm{H})_{\text {ar }} 3095(\mathrm{w})$, $3066(\mathrm{w}), 3015(\mathrm{w}) ; \nu_{\text {as }}\left(\mathrm{CH}_{3}\right) 2962(\mathrm{~m}), \nu_{\text {as }}\left(\mathrm{CH}_{3}\right) 2952(\mathrm{~m}) ; v_{\mathrm{s}}\left(\mathrm{CH}_{3}\right)$ $2905(\mathrm{w}), \quad 2867(\mathrm{w}) ; \quad \nu(\mathrm{C}=\mathrm{C})_{\mathrm{ar}}, \quad \nu(\mathrm{C}=\mathrm{N}) \quad 1659(v s),. \quad 1610(v s)$, 1592(vs.), 1556(m), 1546(m), 1494(m), $1474(\mathrm{~s}), 1467(\mathrm{~s}), 1449(\mathrm{~s})$, 1394(m), 1364(s), 1331(w), 1288(m), 1232(m), 1220(m), $\nu(\mathrm{C}-\mathrm{O})$ 1257(m); $\delta(\mathrm{OClO})$ 1146(vs.), 1121(vs.), 1108(vs.), 1087(vs.), $\gamma(\mathrm{C}-$ $\mathrm{H})_{\mathrm{ar}}, \rho(\mathrm{C}-\mathrm{H})_{\mathrm{ar}}$ 1052(s), $1008(\mathrm{~m}), \quad 958(\mathrm{~m}), \quad 929(\mathrm{~m}), \quad 826(\mathrm{~m})$, 745(m), 636(s), 529(w), 501(w); $\nu_{\text {as }}(\mathrm{FeOFe}) 855(\mathrm{w}), \gamma(\mathrm{ClO}) 626(\mathrm{~s})$.

2.4.2. Method B. Schiff-base ligand $\mathrm{H}_{3} \mathrm{~L}(20.2 \mathrm{mg}, 0.041$ $\mathrm{mmol}$ ) was placed in $50 \mathrm{ml}$ round bottom flask and suspended in $20 \mathrm{ml}$ of MeOH. $5 \mathrm{ml}$ of MeCN/MeOH (1:1 v/v) solution of $\mathrm{Fe}\left(\mathrm{ClO}_{4}\right)_{2}\left(\mathrm{H}_{2} \mathrm{O}\right)_{6}(14.9 \mathrm{mg}, 0.041 \mathrm{mmol})$ was added what resulted in formation of black solution. Such system was stirred for $48 \mathrm{~h}$ at room temperature without sealing, providing direct access of air. Work-up was identical to the one presented in method A. Formed product was determined to be identical to the one formed by the template approach.

\subsection{X-ray crystallography}

Diffraction data were collected at 100(1) K by the $\omega$-scan technique on Agilent Technologies XCalibur four-circle diffractometer with Eos CCD detector, equipped with Nova microfocus $\operatorname{MoK}_{\alpha}$ radiation source $(\lambda=0.71073 \AA)$ for $\mathbf{1}$, and for $\left[\mathrm{H}_{5} \mathbf{L}\right]\left(\mathrm{ClO}_{4}\right)_{2}$ at room temperature on Agilent Technologies SuperNova four-circle diffractometer with Atlas CCD detector and mirror-monochromated $\mathrm{CuK} \alpha$ radiation $(\lambda=1.54178 \AA$ A $)$. The data were corrected for Lorentz-polarization as well as for absorption effects. ${ }^{38}$ Precise unit-cell parameters were determined by a least-squares fit of reflections of the highest intensity, chosen from the whole experiment. The structures were solved with SIR92 (ref. 39) and refined with the full-matrix least-squares procedure on $F^{2}$ by SHELXL-2013. ${ }^{40}$ The structure of 1 contains voids filled with diffused electron density therefore the SQUEEZE procedure ${ }^{41}$ was applied. All non-hydrogen atoms were refined anisotropically, hydrogen atoms were placed in idealized positions and refined as 'riding model' with isotropic displacement parameters set at 1.2 (1.5 for methyl or hydroxyl groups) times $U_{\text {eq }}$ of appropriate carrier atoms. The crystals of 1 (maybe due to the disordered solvent) were of relatively poor quality, and in consequence weak restraints were applied to the displacement parameters of some atoms. The crystals of protonated ligand turned out to be twinned, (which was taken into account during both data reduction and refinement); the BASF factor, describing the content of one of the component ${ }^{41}$ was refined at $79.0(3) \%$.

2.5.1. Crystal data. (1) $\mathrm{C}_{60} \mathrm{H}_{74} \mathrm{Fe}_{2} \mathrm{~N}_{16} \mathrm{O}_{6}{ }^{4+} \cdot 4\left(\mathrm{ClO}_{4}\right)^{-}, M_{\mathrm{r}}=$ 1624.85, triclinic, $P \overline{1}, a=10.6236(17) \AA, b=13.530(2) \AA, c=$ 16.128(2) $\AA$, $\alpha=66.459(15)^{\circ}, \beta=87.591(12)^{\circ}, \gamma=78.066(14)^{\circ}, V$ $=2077.2(6) \AA^{3}, Z=1, F(000)=842, d_{\mathrm{x}}=1.308 \mathrm{~g} \mathrm{~cm}^{-3}, \mu=0.55$ $\mathrm{mm}^{-1}$. 15018 reflections measured, 7301 symmetryindependent $\left(R_{\mathrm{int}}=13.94 \%\right), 2549$ with $I>2 \sigma(I)$. Final $R[I>$ $2 \sigma(I)]=9.86 \%, \mathrm{w} R_{2}[I>2 \sigma(I)]=15.47 \%, R[$ all reflections $]=$ $20.02 \%, \mathrm{w} R_{2}[$ all reflections $]=18.33 \%, S=0.93, \max / \min \Delta \rho=$ $0.80 /-0.40$ e $\AA^{-3}$.

$\left[\mathrm{H}_{5} \mathbf{L}\right]\left(\mathrm{ClO}_{4}\right)_{2}-2\left(\mathrm{C}_{28} \mathrm{H}_{32} \mathrm{~N}_{8} \mathrm{O}\right)^{2+} \cdot 4\left(\mathrm{ClO}_{4}\right)^{-} \cdot \mathrm{C}_{7} \mathrm{H}_{8} \cdot \mathrm{CH}_{3} \mathrm{OH}, M_{\mathrm{r}}=$ 1515.21, triclinic, $P \overline{1}, a=11.4426(5) \AA, b=13.0011(5) \AA, c=$ $24.5126(10) \AA, \alpha=90.991(3)^{\circ}, \beta=91.953(4)^{\circ}, \gamma=92.005(4)^{\circ}, V=$ $3641.7(3) \AA^{3}, Z=2, d_{\mathrm{x}}=1.38 \mathrm{~g} \mathrm{~cm}^{-3}, \mu=2.16 \mathrm{~mm}^{-1}, F(000)=$ 1584. 25627 reflections collected up to $2 \theta=67.5^{\circ}, 12871$ symmetry independent, $\left(R_{\text {int }}=8.60 \%\right), 7644$ with $I>2 \sigma(I)$. Final $R[I>2 \sigma(I)]=10.20 \%, \mathrm{w} R_{2}[I>2 \sigma(I)]=23.13 \%, R[$ all refl. $]=$ $14.69 \%$, $\mathrm{w}_{2}$ [all refl. $]=26.03 \%, S=1.05$, $\max / \min \Delta \rho=1.52 /$ -0.58 e $\AA^{-3}$.

Crystallographic data (excluding structure factors) for the structural analysis has been deposited with the Cambridge Crystallographic Data Centre, no. CCDC-1407322 (1) and CCDC$1482453\left(\left[\mathrm{H}_{5} \mathbf{L}\right]\left(\mathrm{ClO}_{4}\right)_{2}\right) \cdot \dagger$

\subsection{Electrode activation and modification}

All solutions under investigation were prepared prior to each experiment, using Millipore Milli-Q-water or acetonitrile (ACN) $0.1 \mathrm{M} \mathrm{TBAClO}_{4}, 0.1 \mathrm{M} \mathrm{LiClO}_{4}$ or phosphate buffer $(0.6 \mathrm{M} \mathrm{pH}=7)$ served as a supporting electrolyte solution. All solutions were deaerated by argon (99.998\%) before measurements performed at room temperature.

The working electrode was either the bare gold electrode (99.999\%, Polish State Mint) or the gold electrode modified with the Fe-complex 1 of $0.03 \mathrm{~cm}^{2}$ geometric area. A gold sheet was used as an auxiliary electrode $\left(10 \mathrm{~cm}^{2}\right)$, whereas the saturated calomel electrode (SCE) and the $\mathrm{Ag} / \mathrm{Ag}^{+}$in $\mathrm{ACN}$ electrodes were used as reference electrode in aqueous and ACN solution, respectively.

Before any experiment, the bare gold electrode was polished with aluminium slurries of successively decreasing final grades 
down to $0.05 \mu \mathrm{m}$ (Buehler) on polishing cloths (Buehler). Next, the polished electrode was rinsed carefully with acetone and water, respectively. After that the electrode was electrochemically activated by cycling in the potential range between $E=$ $-0.7 \mathrm{~V}$ and $E=0.6 \mathrm{~V} v s$. SCE in the phosphate buffer $(0.06 \mathrm{M}, \mathrm{pH}$ $=7$ ), with the potential scan rate, $\mathrm{d} E / \mathrm{d} t=0.1 \mathrm{~V} \mathrm{~s}^{-1}$ until a stable cyclic voltammogram (acronyms $\mathrm{CV}$ or $i-E$ curve) was obtained. This procedure avoids structural changes on the gold surface. ${ }^{42}$

In order to obtain a gold electrode modified with SAM made of $\mathbf{1}$, the activated Au template was electrochemically cycled in $0.1 \mathrm{M} \mathrm{TBAClO}_{4}$ supporting electrolyte solution in ACN with addition of $0.001 \mathrm{M}$ Fe-complex at $\mathrm{d} E / \mathrm{d} t=0.1 \mathrm{~V} \mathrm{~s}^{-1}$, until a stable $\mathrm{CV}$ was obtained. The electrochemical properties of the modified electrode were checked over two weeks and were found to be stable. The consecutive series of voltammetric experiments performed each day were separated by rest periods at open circuit in without solution. Before re-use in electrochemical measurements electrode was washed with acetone and dried in an argon stream. The self-assembled layers can be removed from the modified Au surface by dipping it (for about 5 minutes) in a Piranha solution, i.e. in a mixture $3: 1$ of aqueous solutions of $96 \% \mathrm{H}_{2} \mathrm{SO}_{4}$ and $30 \% \mathrm{H}_{2} \mathrm{O}_{2}$. In order to recover the proposed sensors, the above described procedure of polishing, activation and modification of the bare Au electrodes must be repeated.

\section{Results and discussion}

Subcomponent self-assembly approach ${ }^{43}$ allowed us to synthesize new, bimetallic iron(III) complex, metal ions bound within $\mathrm{N}^{\prime} \mathrm{N}^{\prime} \mathrm{O}^{\prime} \mathrm{N}^{\prime} \mathrm{N}$ Schiff-base scaffold $\mathrm{H}_{3} \mathrm{~L}$ in unprecedented manner (cf. Section 3.1 and Fig. 1). During the course of the reaction, native $\mathrm{Fe}(\mathrm{II})$ metal ions are oxidized by air to $\mathrm{Fe}(\mathrm{III})$ species and coordinate with in situ formed ligand $\mathrm{H}_{3} \mathbf{L}$ to form $\left[\mathrm{Fe}_{2}\left(\mathrm{H}_{3} \mathbf{L}\right)_{2}\right.$ $\left.(\mathrm{MeOH})_{2}(\mu-\mathrm{OMe})_{2}\right]\left(\mathrm{ClO}_{4}\right)_{4} \quad$ (1). Electrospray ionization mass spectrometry, elementary analysis as well as FT-IR spectroscopy confirmed formation of FeOFeO bridged bimetallic species, whereas its structure in the solid state has been unambiguously confirmed via single X-ray crystallography. Despite the fact that the major species found under ESI-MS studies are monometallic $[\mathrm{Fe}(\mathrm{HL})]^{+}$positive ions, we believe the solid state structure is retained in solution on the basis of the following premises: (i) it is still possible to find signals from bimetallic species $\left[\mathrm{Fe}_{2}(\mathrm{HL})_{2}-\mathrm{H}^{+}\right]^{+},\left[\mathrm{Fe}_{2}(\mathrm{HL})_{2}(\mathrm{MeO})\right]^{+},\left\{\left[\mathrm{Fe}_{2}(\mathrm{HL})_{2}\right]\left(\mathrm{ClO}_{4}\right)\right\}^{+}(\mathrm{ii})$ all observed systems are amenable to the applied cone-voltage. It is also of notice that observed $\mu$-oxo $\mathrm{Fe}_{2} \mathrm{O}_{2}$ motif is of relevance with regard to nonheme iron-containing enzymes ${ }^{\mathbf{4 - 4 6}}$ and quite unexpectedly herein, it is formed via coordination with adventitious methoxy groups rather than with exploitation of the phenoxy moieties of $\mathrm{H}_{3} \mathbf{L}$ ligand. The latter situation was observed in $\left[\mathrm{Mn}_{2}\left(\mathrm{H}_{2} \mathbf{L}\right)_{2}\right]\left(\mathrm{ClO}_{4}\right)_{2}$ manganese(II) complex, which we have recently demonstrated to form electrochemical sensor at the Au template with regard to sensing of dopamine in the presence of interfering biogenic compounds. ${ }^{36}$ Herein however, we also demonstrated that the template approach is not the only one that leads to the desired product. It was possible to isolate the new Schiff-base ligand and subdue it to the full spectroscopic characterization. Furthermore, it was possible to transform it into a diprotonated cationic salt $\left[\mathrm{H}_{5} \mathbf{L}\right]\left(\mathrm{ClO}_{4}\right)_{2}$ and unambiguously confirm its structure in the solid state (vide infra). We were able to complexate $\mathrm{H}_{3} \mathrm{~L}$ with iron(II) salt and the final product turned out to be identical with the one obtained via the subcomponent self-assembly approach.

\subsection{Crystallographic data}

Both systems that comprise the $\mathrm{H}_{3} \mathbf{L}$ Schiff-base ligand have been crystallized and characterized in the solid state, either in the form of dicationic salt $\left[\mathrm{H}_{5} \mathbf{L}\right]^{2+}$ or bimetallic $\mathrm{Fe}(\mathrm{III})$ complex (1).

3.1.1. $\left[\mathbf{H}_{5} \mathrm{~L}\right]\left(\mathbf{C l O}_{4}\right)_{2}$. There are two symmetry-independent cations in the asymmetric part of the unit cell, and they have very similar geometry (Fig. 2). One can however note, that relative orientation of $\mathrm{OH}$ and isopropyl groups are reverse in both molecules $(\mathrm{OH}$ hydrogen in each case makes reasonable hydrogen bonds).

The cations are almost planar, the dihedral angles between the mean planes of the terminal ring systems are $13.5^{\circ}$ and $10.2^{\circ}$ (the relevant geometrical features of the ligands are listed in the Table S1, ESI $\dagger$ ). Intramolecular $\mathrm{OH} \cdots \mathrm{N}$ hydrogen bonds help in adopting such conformation. In the crystal structure, besides four perchlorate anions, methanol and (heavily disordered) toluene molecules were found. The crystal structure results - apart from the electrostatic interactions between charged species - from the extensive network of hydrogen bonds, involving all strong hydrogen bond donors (Fig. 3). The details of the hydrogen bonds are listed in Table S2, ESI. $\dagger$

3.1.2. $\left[\mathrm{Fe}_{2}\left(\mathrm{H}_{3} \mathrm{~L}\right)_{2}(\mathbf{M e O H})_{2}(\boldsymbol{\mu}-\mathrm{OMe})_{2}\right]\left(\mathrm{ClO}_{4}\right)_{4}$. The complex molecule is centrosymmetric $\left(C_{\mathrm{i}}\right.$-symmetrical $)$, the middle point of the $\mathrm{Fe} \cdots \mathrm{Fe}$ segment lies at the center of symmetry in the space group $P \overline{1}$ (Fig. 4).

Table 1 lists the relevant geometrical parameters. Fe atoms are six-coordinated, by three atoms (NNO) from $\mathrm{H}_{3} \mathbf{L}$ molecule: two oxygen atoms from bridging methoxy anion, and one oxygen atom from additional methanol. The coordination is closed to octahedral ( $c f$. Table 1), and the central FeOFeO ring is planar. This was also supported by SHAPE measurement calculations, ${ }^{47,48}$ which indicate the level of deviation from the perfect polyhedron $(\mathrm{S}=\mathrm{O})$ by means of continuous shape measurements (CShM). Indeed, the lowest value was encountered for octahedron $(S=2.04)$, showing that the site symmetry is best described as $O_{\mathrm{h}}$. We did also compare the symmetry of

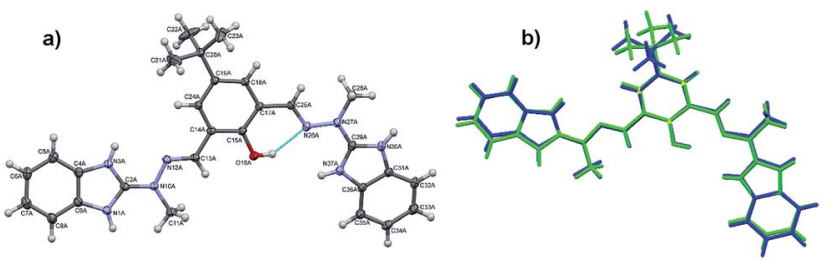

Fig. 2 Anisotropic ellipsoid representation of the molecule $A$ of a $\left[\mathrm{H}_{5} \mathrm{~L}\right]^{2+}$ cation (a); ellipsoids are drawn at the $50 \%$ probability level, hydrogen atoms are shown as spheres of arbitrary radii, hydrogen bond is shown as thin blue line; comparison of two symmetry-independent cations (fitting of the central rings $-b$ ). 


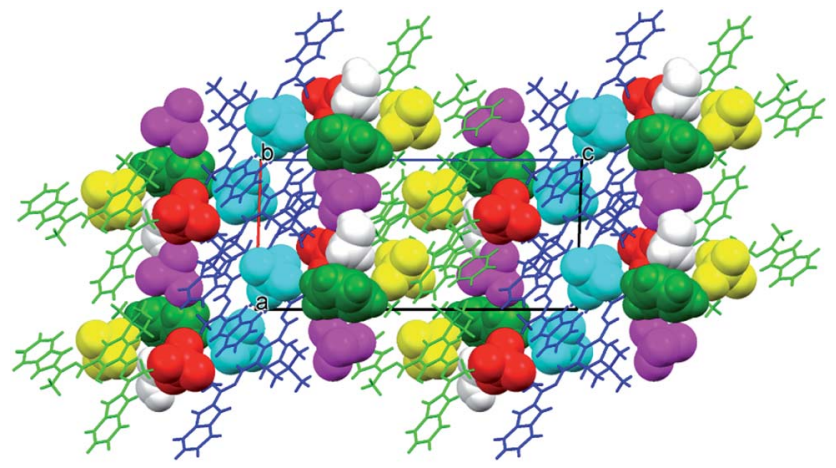

Fig. 3 A crystal structure of $\left[\mathrm{H}_{5} \mathrm{~L}\right]\left(\mathrm{ClO}_{4}\right)_{2}$ cation as seen along $b$ direction. Anions and solvent molecules are shown in van der Waals spheres representation in order to visualize their filling-structure role.

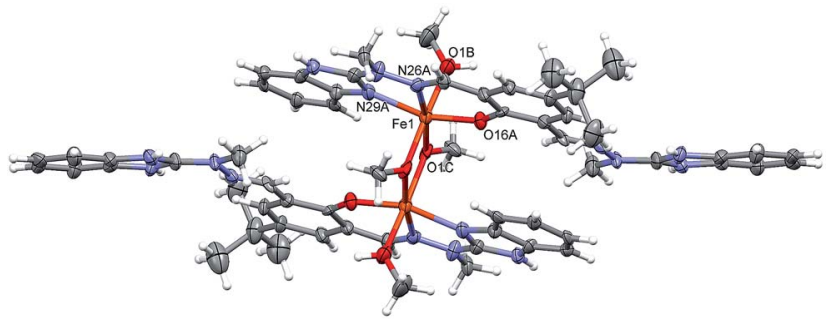

Fig. 4 Anisotropic ellipsoid representation of the cation; ellipsoids are drawn at the $30 \%$ probability level, hydrogen atoms are shown as spheres of arbitrary radii. The primed atoms are related with the unprimed ones by symmetry operation $1-x, 1-y, 1-z$.

Table 1 Relevant geometrical parameters $\left(\AA \AA{ }^{\circ}\right)$ with s.u.'s in parentheses

\begin{tabular}{llll}
\hline Bond length $[\AA]$ & & Bond angle $\left[{ }^{\circ}\right]$ & \\
\hline Fe1-O16A & $1.879(16)$ & O16A-Fe1-N29A & $157.1(3)$ \\
Fe1-N29A & $2.052(7)$ & O1C-Fe1-N26A & $168.8(3)$ \\
Fe1-N26A & $2.185(8)$ & O1B-Fe1-O1C & $169.5(3)$ \\
Fe1-O1C & $1.957(6)$ & Fe1-O1C-Fe1 & $103.0(3)$ \\
Fe1-O1B & $2.101(7)$ & - & - \\
Fe1-O1C & $2.002(7)$ & - & - \\
\hline
\end{tabular}

the previously synthesized $\left[\mathrm{Mn}_{2}\left(\mathrm{H}_{2} \mathbf{L}\right)_{2}\right]\left(\mathrm{ClO}_{4}\right)_{2}$ complex (Table S3, ESI $\dagger$ ) and concluded that the trigonal prism geometry of $\mathrm{Mn}$ (II) cations ( $D_{3 \mathrm{~h}}$ site symmetry) might indirectly confer to different conformation of ligand $\mathrm{H}_{3} \mathbf{L}$ and thus different chemisorption onto the Au electrode (Fig. S1 and S2 $\dagger$ ). The ligands are slightly twisted dihedral angles between mean planes of the terminal ring systems are $18.3(2)^{\circ}$.

In the crystal structure there are voids which are filled by some electron density, interpreted as disordered water molecules. Hydrogen bonds $(\mathrm{N}-\mathrm{H} \cdots \mathrm{O}$ and $\mathrm{O}-\mathrm{H} \cdots \mathrm{O})$ connect the complex with perchlorate anions, and - together with the electrostatic interactions between charged species - might be regarded as a driving force for the crystal structure (Fig. 5).

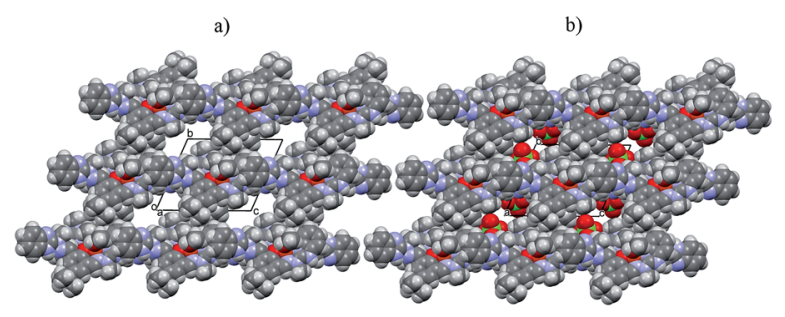

Fig. 5 Crystal lattice of $\left[\mathrm{Fe}_{2}\left(\mathrm{H}_{3} \mathrm{~L}\right)_{2}(\mathrm{MeOH})_{2}(\mu-\mathrm{OMe})_{2}\right]\left(\mathrm{ClO}_{4}\right)_{4}$ complex as seen along a direction; voids present within the crystal lattice are filled by perchlorate counterions (as shown in (b) and omitted in (a)).

\subsection{Electrooxidation of prepared complex on a gold electrode and its characterization}

The cyclic voltammograms of the bare polycrystalline gold electrode recorded in $0.1 \mathrm{M}$ tetrabutyloammonium perchlorate $\left(\mathrm{TBAClO}_{4}\right)$ in acetonitrile (ACN) as a supporting electrolyte solution is presented on Fig. 6 a (curve 1). CV obtained in $0.1 \mathrm{M}$ $\mathrm{LiClO}_{4}$ in ACN solution is attached to Fig. 6a (curve 2) for comparative issues.

A pair of anodic/cathodic peaks, observed at curve 1 in Fig. $6 \mathrm{a}$, at $1.65 \mathrm{~V} v s . \mathrm{Ag} / \mathrm{Ag}^{+}$in the anodic scan and at $1.15 \mathrm{~V} v s$. $\mathrm{Ag} / \mathrm{Ag}^{+}$in the cathodic scan respectively is responsible for oxidation and reduction of a gold oxide layer. Moreover, a couple of peaks visible at $-1.75 \mathrm{~V}$ and $-1.35 \mathrm{~V} \mathrm{vs}$. $\mathrm{Ag} / \mathrm{Ag}^{+}$is assigned to the electrochemical behavior of TBA cation. The last conclusion is very important from the electrochemical point of view, since in certain papers that concern complexes studied in the same supporting electrolyte (ACN), the latter pair of peaks was incorrectly considered as coming from the studied complex
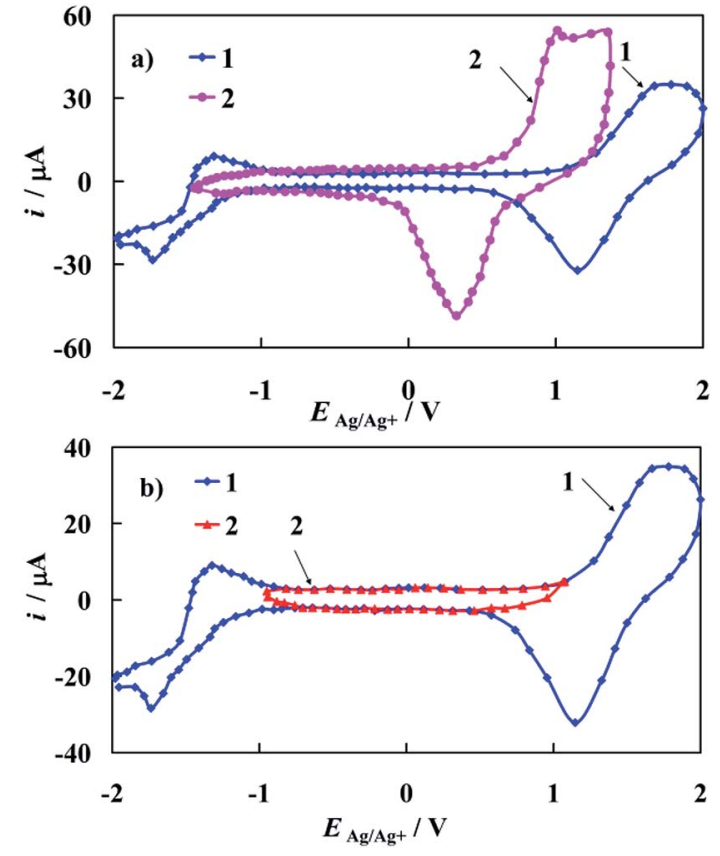

Fig. 6 (a) Cyclic voltammograms of polycrystalline gold electrode recorded in: (1) $0.1 \mathrm{M} \mathrm{TBAClO}_{4}$ and (2) in $0.1 \mathrm{M} \mathrm{LiClO}_{4} \mathrm{ACN}$ solution. (b) (1) The same solution as in 1(a) with (2) depicting the potential range of the electrical double layer of gold electrode. $\mathrm{d} E / \mathrm{d} t=0.1 \mathrm{~V} \mathrm{~s}^{-1}$. 
instead of TBA cation. It is also worth noting that this pair of peaks should be not assigned to the $\mathrm{ClO}_{4}{ }^{-}$anion. This is confirmed by the shape of curve 2 presented in Fig. 6a. Curves 1 and 2 differ considerably despite being recorded in the solutions of supporting electrolyte with different cations. A characteristic feature of the bare gold electrode (Fig. 6b, curve 1) is a wide potential region where no faradic reactions occur (Fig. 6b, curve 2). In this potential region only a charging and discharging of the electrical double layer of the gold electrode occurs (Fig. 6b, curve 2), therefore other electrochemical processes can be studied in this electrode potential window.

The representative set of cyclic voltammograms recorded at the gold electrode in the supporting electrolyte solution and in the presence of the increasing concentration of $\left[\mathrm{Fe}_{2}\left(\mathrm{H}_{3} \mathbf{L}\right)_{2}\right.$ $\left.(\mathrm{MeOH})_{2}(\mu-\mathrm{OMe})_{2}\right]\left(\mathrm{ClO}_{4}\right)_{4}$ complex is depicted in Fig. 7.

As can be seen, a successive increase of the amount of Fe-complex in solution results in strong adsorption and blocking of the gold surface in the potential range of gold oxide oxidation/reduction. The range of the electric double layer almost does not change and, again the electrode surface is covered by the studied complex in the region of TBA cation. It should be noted that on the recorded $i-E$ curves, peaks which would demonstrate the presence of $\mathrm{Fe}(\mathrm{III})$ in the used complex molecules are not present. This stands in contrast with previously presented Mn-complex within the same Schiff base scaffold $\mathrm{H}_{3} \mathrm{~L}$ as dopamine sensor, ${ }^{36}$ but becomes understandable when comparison of their structures is made.

Formation of self-assembled monolayers (SAMs) from metallosupramolecular architectures on the solid surfaces is dependent on: (i) information encoded within organic ligand and chosen metal ion that affect the final structure of the complex; (ii) nature of the substrate (template) that influences the adsorption behavior of the system under study i.e. the electrocatalyst. Presented bicompartmental Schiff-base ligand has the potential to form various metal ion complexes, in accordance to the exhibited conformation (Fig. 8).

$\mathrm{H}_{3} \mathbf{L}$ ligand was found to exhibit conformation $\mathbf{C}$ in the recently published ${ }^{36}$ electrocatalyst $\left[\mathrm{Mn}_{2}\left(\mathrm{H}_{2} \mathbf{L}\right)_{2}\right]\left(\mathrm{ClO}_{4}\right)_{2}$, whereas herein presented $\left[\mathrm{Fe}_{2}\left(\mathrm{H}_{3} \mathbf{L}\right)_{2}(\mathrm{MeOH})_{2}(\mu-\mathrm{OMe})_{2}\right]\left(\mathrm{ClO}_{4}\right)_{4}$ complex

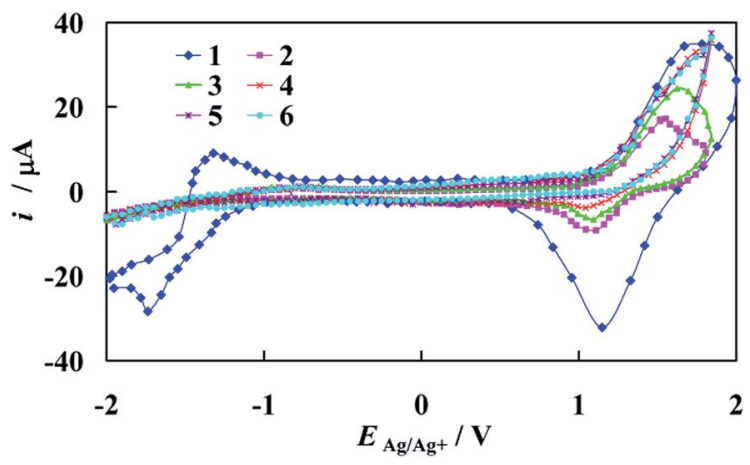

Fig. 7 Cyclic voltammograms of polycrystalline gold electrode recorded in: (1) a supporting electrolyte solution: $0.1 \mathrm{M} \mathrm{TBAClO}_{4}$ in ACN and with addition of (2): $1 \mu \mathrm{M}$; (3) $10 \mu \mathrm{M}$ and (4) $50 \mu \mathrm{M}$; (5) $100 \mu \mathrm{M}$; (6) $1000 \mu \mathrm{M}$ of the $\left[\mathrm{Fe}_{2}\left(\mathrm{H}_{3} \mathrm{~L}\right)_{2}(\mathrm{MeOH})_{2}(\mu-\mathrm{OMe})_{2}\right]\left(\mathrm{ClO}_{4}\right)_{4} \cdot \mathrm{d} E / \mathrm{d} t=0.1 \mathrm{~V}$ $\mathrm{s}^{-1}$.

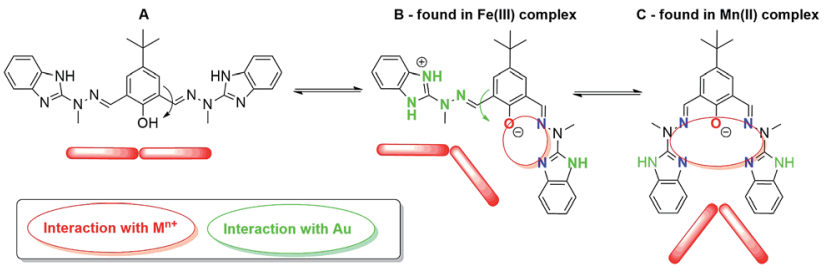

Fig. 8 Conformation changes of ligand $\mathrm{H}_{3} \mathrm{~L}$ that outcome the final structure of $\left[\mathrm{Fe}_{2}\left(\mathrm{H}_{3} \mathrm{~L}\right)_{2}(\mathrm{MeOH})_{2}(\mu-\mathrm{OMe})_{2}\right]\left(\mathrm{ClO}_{4}\right)_{4}$ complex; A - transoid-transoid, B - transoid-cisoid, C - cisoid-cisoid.

exhibits conformation B. Bearing in mind that both $\mathrm{Mn}$ (II) and $\mathrm{Fe}(\mathrm{III})$ ions are isoelectronic, such situation is unprecedented and is of prime importance, thus resulting in two important implications. Firstly, we have established that previously formed conformation $\mathbf{C}$ that results in shielded, $\mu$-phenoxo bridged bimetallic complexes is not mandatory to form stable composites at gold electrode, since surface coverage of 1 at $\mathrm{Au}$ template has been achieved herein (no hydrolysis of iron was observed) as well as is permanent under ambient conditions (vide infra). Secondly, the mode of adsorption may be anticipated to differ, since relative orientation of the $\mathrm{NH}$ groups from benzimidazole moieties in iron and manganese electrocatalysts varies. Please also note that despite being isoelectronic, the central metal ions differ in the symmetry as revealed by SHAPE calculations (Section 3.1.). As a result, planar chemisorption of complex $\mathbf{1}$ is anticipated, contrary to pendant-type chemisorption in $\left[\mathrm{Mn}_{2}\left(\mathrm{H}_{2} \mathbf{L}\right)_{2}\right]\left(\mathrm{ClO}_{4}\right)_{2}$ i.e. perpendicular with respect to the orientation of Mn(II)-Mn(II) molecular axis. (ESI - Fig. S1†) Such situation would result in $c a$. 9 times lower concentration of Fecomplex than Mn-complex at the surface of the electrode. This would be the reason that ratio of the Fe concentration to the concentration of all complex in the supporting electrolyte solution is very small, firmly too low, to give peak which may be assigned to the $\mathrm{Fe}(\mathrm{III})$ ion.

By taking into account the crystallographic structure of the studied $\left[\mathrm{Fe}_{2}\left(\mathrm{H}_{3} \mathbf{L}\right)_{2}(\mathrm{MeOH})_{2}(\mu-\mathrm{OMe})_{2}\right]\left(\mathrm{ClO}_{4}\right)_{4}$ complex, it is evident that it can be considered as a good candidate to form SAMs on the bare gold surface. It is commonly known that gold is characterized by a good affinity to nitrogen.$^{\mathbf{4 9 5 0}}$ It is generally accepted that chemisorption of modified functionalized compounds on gold is preceded by the oxidative abstraction of hydrogen in our case from $\mathrm{N}-\mathrm{H}$ bonds, whereas the "rest" of modified molecules create an ordered structure at the electrode turned at a tilt angle towards the electrolyte solution..$^{51}$ The firm attachment of Fe-complex to the gold electrode surface ( $\mathrm{Au}$ ) herein is realized via the covalent bonds between the $\mathrm{Au}$ and $\mathrm{N}$ atoms from Schiff base ligand studied complex molecule as well as $\pi$-stacking interactions. (ESI - Fig. S2†) This has been also confirmed by SEM images of the formed $\left[\mathrm{Fe}_{2}\left(\mathrm{H}_{3} \mathbf{L}\right)_{2}(\mathrm{MeOH})_{2}(\mu-\right.$ $\left.\mathrm{OMe})_{2}\right]\left(\mathrm{ClO}_{4}\right)_{4 /} \mathrm{Au}$ composite (ESI - Fig. S3†).

A strong adsorption at the gold electrode surface was confirmed in separate experiments in which the electrode was cycled in solution with the Fe-complex, and then rinsed copiously with ACN, drying and dipped in the fresh supporting electrolyte. The resulting voltammogram was the same as before 
electrode washing. Such an experiment, with the same electrode has been repeated each day during two weeks and the recorded $i-E$ curve did not change in shape as compared to that obtained at the beginning of the presented project. We also managed to isolate and characterize the new Schiff-base ligand $\mathrm{H}_{3} \mathbf{L}$ to check if the deposition of the sole ligand would be possible on the bare Au electrode. Remarkably, the electrochemically mediated deposition of ligand does not occur, what is another proof that formation of SAMs - here in the form of $\left[\mathrm{Fe}_{2}\left(\mathrm{H}_{3} \mathbf{L}\right)_{2}(\mathrm{MeOH})_{2}(\mu-\right.$ $\left.\mathrm{OMe})_{2}\right]\left(\mathrm{ClO}_{4}\right)_{4} / \mathrm{Au}$ composite material - is possible, provided that $\mathrm{H}_{3} \mathrm{~L}$ was complexated with metallic centers.

\subsection{Oxidation of epinephrine at bare and modified gold electrodes}

From literature it is well know that formation of self-assembled monolayers (SAMs) are one of the means for functionalization of various electrodes. They are used in the cases when investigation of some compounds on unmodified electrodes disappoints or becomes troublesome. For the above described reasons, such a case is an immanent trait during epinephrine electrooxidation on the bare gold electrode.

Electrochemical oxidation of epinephrine goes through three steps, according to the ECE mechanism (where: E and C denotes the electrochemical and the chemical step, respectively) presented below in Fig. 9. ${ }^{3}$

Fig. 10a shows the stable voltammetric response (after the $5^{\text {th }}$ scan) of the bare gold electrode in the presence of EP. The epinephrine oxidation at the bare gold electrode proceeds in two potential ranges. The anodic peak with a maximum at $E=$ $0.5 \mathrm{~V} v s . \mathrm{Ag} / \mathrm{Ag}^{+}$corresponds to irreversible electrooxidation of EP to $o$-epinephrinequinone after exchange of 2 electrons and 2 protons. Epinephrinequinone contains both an electrondeficient ring and an electron-donating amine group. When the latter group becomes deprotonated, the molecule can undergo a 1,4 Michael addition, which results in a cyclization reaction. ${ }^{48}$ Therefore, in the next step o-epinephrinequinone transforms into leucoepinephrinechrome via a chemical intramolecular 1,4-Michael addition.,50 A subsequent couple of peaks at $0.05 \mathrm{~V}$ vs. $\mathrm{Ag} / \mathrm{Ag}^{+}$and $0.11 \mathrm{~V}$ vs. $\mathrm{Ag} / \mathrm{Ag}^{+}$, appearing during the following cathodic and anodic scans, is related to the reversible electrooxidation of leucoepinephrinechrome to<smiles>CNCC(O)c1ccc(O)c(O)c1</smiles><smiles>CNCC(O)C1=CC(=O)C(=O)C=C1</smiles><smiles>CNCC(O)C1=CC(=O)C(=O)C=C1</smiles>

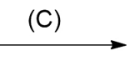<smiles>CN1CC(O)c2cc(O)c(O)cc21</smiles><smiles>CN1CC(O)c2cc(O)c(O)cc21</smiles>

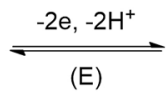

Fig. 9 Electrooxidation of epinephrine on electrodes.
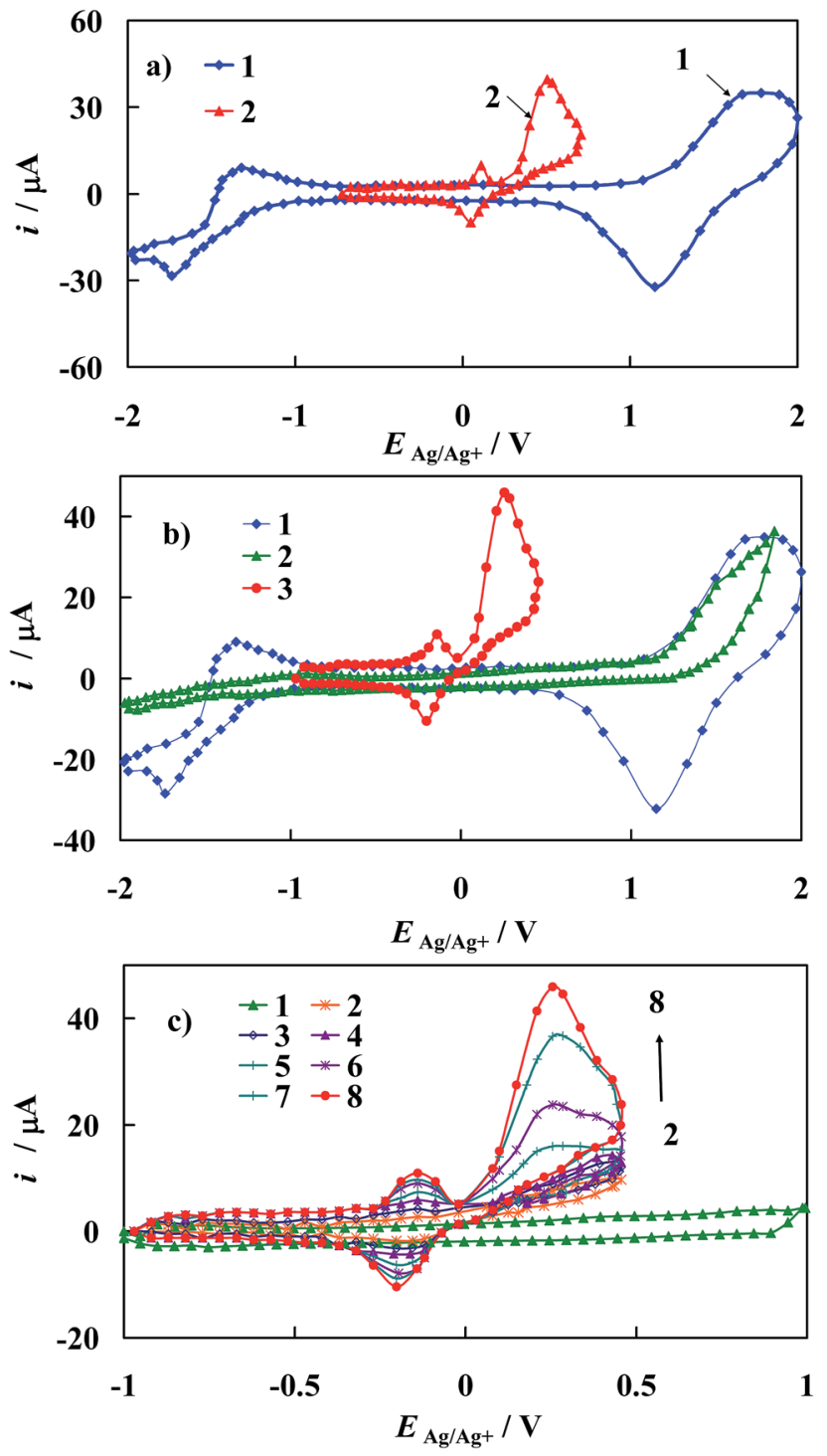

Fig. 10 (a) Cyclic voltammograms of polycrystalline gold electrodes recorded in $0.1 \mathrm{M} \mathrm{TBAClO}_{4}$ in $\mathrm{ACN}$ (1) and with addition of (2) $500 \mu \mathrm{M}$ of EP. (b) (1) Cyclic voltammograms of polycrystalline gold electrodes recorded in $0.1 \mathrm{M} \mathrm{TBAClO}_{4}$ in $\mathrm{ACN}$ and with addition of: (2) $1000 \mu \mathrm{M}$ of the $\left[\mathrm{Fe}_{2}\left(\mathrm{H}_{3} \mathrm{~L}\right)_{2}(\mathrm{MeOH})_{2}(\mu-\mathrm{OMe})_{2}\right]\left(\mathrm{ClO}_{4}\right)_{4}$; (3) the same as in (2) after addition of $500 \mu \mathrm{M}$ EP. (c) Cyclic voltammograms of polycrystalline gold electrode recorded in $0.1 \mathrm{M} \mathrm{TBAClO}_{4}$ in $\mathrm{ACN}$ covered with 1000 $\mu \mathrm{M}$ of the Fe-complex (1) and (2) the same as in (1) after addition of 0.01 $\mu \mathrm{M} \mathrm{EP}$; (2) $0.1 \mu \mathrm{M} \mathrm{EP}$; (3) $1 \mu \mathrm{M} \mathrm{EP;} \mathrm{(4)} 10 \mu \mathrm{M} \mathrm{EP;} \mathrm{(5)} 100 \mu \mathrm{M} \mathrm{EP;} \mathrm{(6)} 200$ $\mu \mathrm{M} \mathrm{EP} ;$ (7) $400 \mu \mathrm{M} \mathrm{EP}$; (8) $500 \mu \mathrm{M} \mathrm{EP}$. dE/d $t=0.1 \mathrm{~V} \mathrm{~s}^{-1}$.

epinephrinechrome and its regeneration after reversal of the potential scan direction.

From comparison of the results presented in Fig. 10a and b, it is evident that a remarkable catalytic effect in epinephrine electrooxidation to $o$-epinephrinequinone can be achieved on gold electrode modified with $\left[\mathrm{Fe}_{2}\left(\mathrm{H}_{3} \mathbf{L}\right)_{2}(\mathrm{MeOH})_{2}(\mu-\mathrm{OMe})_{2}\right]$ $\left(\mathrm{ClO}_{4}\right)_{4}$. This is manifested as a substantial shift of the corresponding voltammetric peaks towards the more negative direction accompanied by an increase in the current response at the potential of oxidation peak maximum in comparison with that of the bare gold electrode. Both these effects confirmed 
electrocatalytic improvement of the kinetics of the electrode reactions at electrochemically modified electrodes. ${ }^{52}$

The $i-E$ curves recorded on the Au/ $\mathbf{1}$ modified electrode with increasing concentration of EP in the supporting electrolyte solution (Fig. 10c) suggest the presence of specific interactions of the epinephrine with the electrode material and/or with SAM of $\mathbf{1}$, which results in a decrease of the energy barrier for the oxidative electron transfer. This conclusion is supported by the Tafel slopes comprised between $140 \mathrm{mV}$ for $\mathrm{Au} / \mathbf{1}$ electrode and $220 \mathrm{mV}$ for the bare Au electrode. ${ }^{52}$

As mentioned above and visualized in Fig. 11a, the detection of epinephrine in the presence of other biogenic compounds like ascorbic acid on the bare gold electrode is precluded. For example, values of the peak separation $\left(\Delta E_{\mathrm{EP}-\mathrm{AA}}\right)$ for the $500 \mu \mathrm{M}$ EP concentration in the mixture with $5000 \mu \mathrm{M}$ AA observed on unmodified gold electrode is only $0.05 \mathrm{~V}$. As a result, the cyclic voltammetric responses of these two compounds practically overlap. Remarkably, this problem is removed when the modified gold electrode developed in this work is applied in analysis of the mixture containing EP and AA (Fig. 11b). In the latter case, the peak potential separation $\Delta E_{\mathrm{EP}-\mathrm{AA}}$ increases to $0.45 \mathrm{~V}$. Based on the crystallographic structure of $\left[\mathrm{Fe}_{2}\left(\mathrm{H}_{3} \mathbf{L}\right)_{2}(\mathrm{MeOH})_{2}(\mu-\right.$ $\left.\mathrm{OMe})_{2}\right]\left(\mathrm{ClO}_{4}\right)_{4}$, it seems reasonable to conclude that its chemisorption on Au template leads to a SAM matrix with an excess of negative charge in the form of free electron pairs localized on $\mathrm{N}$ atoms of the Fe-complex in the chemisorbed layer. Thus, the electrode surface covered by the prepared $\left[\mathrm{Fe}_{2}\left(\mathrm{H}_{3} \mathbf{L}\right)_{2}(\mathrm{MeOH})_{2}(\mu-\right.$ $\left.\mathrm{OMe})_{2}\right]\left(\mathrm{ClO}_{4}\right)_{4}$ complex film should repel anionic species through electrostatic repulsion while cationic species should be electrostatically attracted. Taking into account the values of $\mathrm{p} K_{\mathrm{a}}$ $=9.9$ and $\mathrm{p} K_{\mathrm{a}}=4.1$ of epinephrine and ascorbic acid, respectively, ${ }^{53}$ it is reasonable to conclude that under presented experimental conditions, EP exists in its cationic form while AA in its anionic form. It should be noted that the above given $\mathrm{p} K_{\mathrm{a}}$ values were determined in water, alas the absolute $\mathrm{p} K_{\mathrm{a}}$ values will be significantly higher in non-aqueous solvent, ${ }^{54,55}$ yet it will not affect final electrostatic forms of EP and AA. Thus, the positive potential shift of the EP peak current may be attributed to the electrostatic attraction between the positively charged EP and the negatively charged self-assembled layer. Moreover a repulsive interaction between the negatively charged of AA and the negatively charged SAM would be the reason for the movement of the peak current of AA towards the negative potential values, as is observed on applied modified electrode (Fig. 11b).

The latter behavior confirms that the modified gold electrode prepared in this paper may be successfully used for in vitro quantitative determination of EP in the presence of excess of AA. It should be emphasized as well that electrostatic interactions are reciprocal to dielectric constant of the solvent medium, therefore effect of solvent would be diminished, thus resulting in enhancement of interactions between adsorbed SAMs of $\left[\mathrm{Fe}_{2}\left(\mathrm{H}_{3} \mathbf{L}\right)_{2}(\mathrm{MeOH})_{2}(\mu-\mathrm{OMe})_{2}\right]\left(\mathrm{ClO}_{4}\right)_{4}$ and EP/AA compounds. This may in turn contribute to the observed electrocatalytic oxidation effect.

Information on the detection sensitivity of new voltammetric sensor towards determination of EP in the presence of interfering AA was obtained from experiments performed by
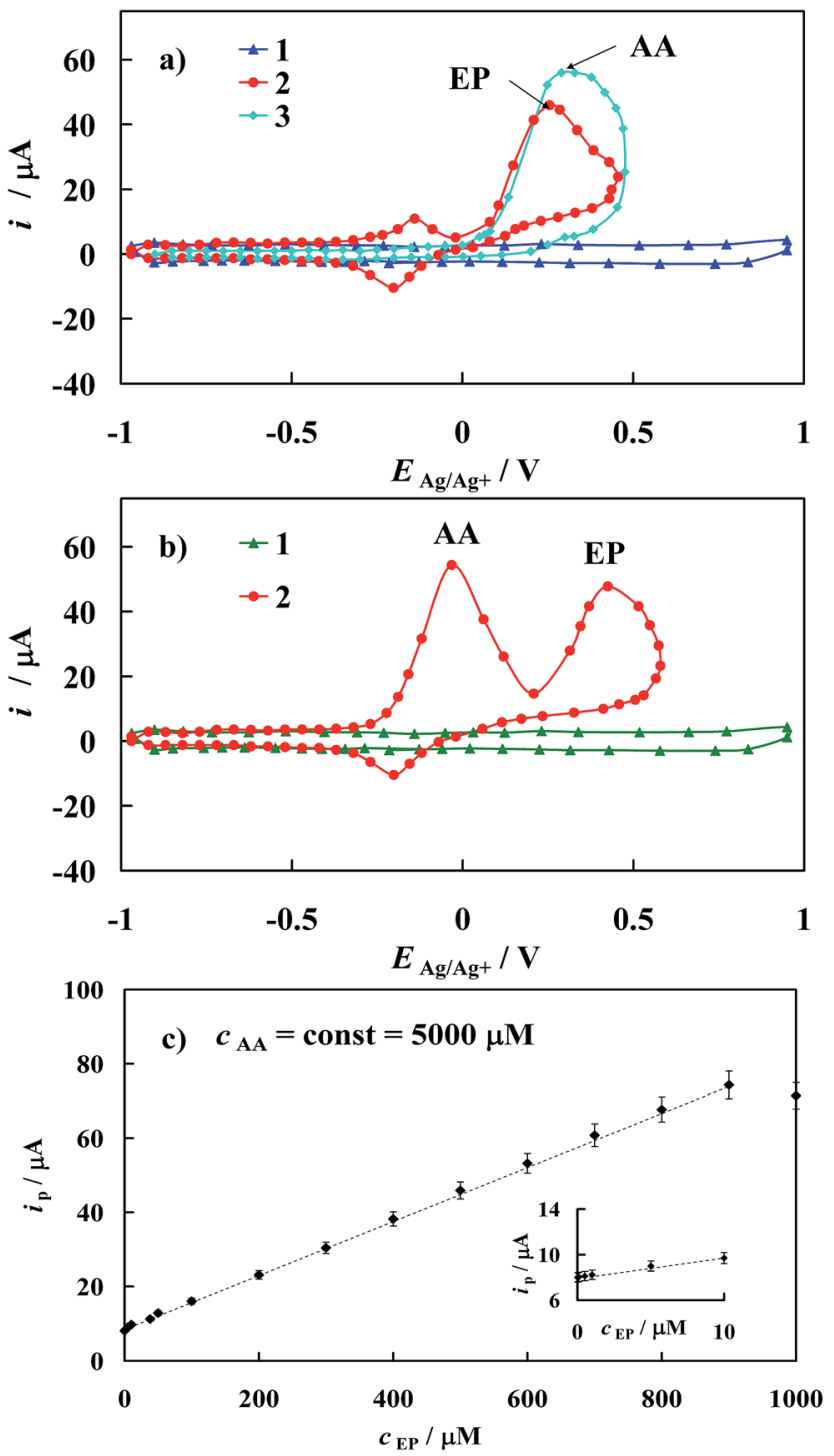

Fig. 11 (a) Cyclic voltammograms recorded in $0.1 \mathrm{M} \mathrm{TBAClO}_{4}$ in $\mathrm{ACN}$ in the region of the electric double layer of polycrystalline gold electrode (1); and the same as in (1) after addition of $500 \mu \mathrm{M}$ EP (2) and $5000 \mu \mathrm{M} \mathrm{AA}$ (3). $\mathrm{d} E / \mathrm{d} t=0.1 \mathrm{~V} \mathrm{~s}^{-1}$. (b) Cyclic voltammograms recorded in $0.1 \mathrm{M} \mathrm{TBAClO}_{4}$ in $\mathrm{ACN}$ in the region of the electric double layer of polycrystalline gold electrode covered with $1000 \mu \mathrm{M}$ of the $\left[\mathrm{Fe}_{2}\left(\mathrm{H}_{3}-\right.\right.$ $\left.\mathrm{L})_{2}(\mathrm{MeOH})_{2}(\mu-\mathrm{OMe})_{2}\right]\left(\mathrm{ClO}_{4}\right)_{4}(1)$ and the same as in (1) after addition of the mixture of $500 \mu \mathrm{M} \mathrm{EP}+5000 \mu \mathrm{M} \mathrm{AA} . \mathrm{d} E / \mathrm{d} t=0.1 \mathrm{~V} \mathrm{~s}^{-1}$. (c) The relationship of the peak current of epinephrine oxidation to epinephrinequinone in the presence of ascorbic acid at constant concentration $(5000 \mu \mathrm{M})$ versus epinephrine concentration in $0.1 \mathrm{M}$ $\mathrm{TBAClO}_{4}$ in $\mathrm{ACN}$ for modified gold electrodes with SAMs of Fecomplex; $\mathrm{d} E / \mathrm{d} t=0.1 \mathrm{~V} \mathrm{~s}^{-1},\left(R^{2} \geq 0.9997\right)$.

changing the concentration of EP with that of AA kept constant, Fig. 11c. Analysis was carried out over the range of $0.01 \mu \mathrm{M}$ to $1000 \mu \mathrm{M}$ of $\mathrm{EP}$ at constant AA concentration equal to $5000 \mu \mathrm{M}$. A linear relationship of the oxidation current versus epinephrine concentration $\left(c_{\mathrm{EP}}\right)$ with the correlation coefficient $R^{2} \geq 0.9997$ has been observed over the range of $0.01 \mu \mathrm{M}$ to $900 \mu \mathrm{M}$, Fig. 11c and may be described by the following regression equations: $i_{\mathrm{p}}$ $[\mu \mathrm{M}]=(845 \pm 9) \times 10^{-2}+(740 \pm 8) \times 10^{-4} c_{\mathrm{EP}}[\mu \mathrm{M}]$. The 
detection sensitivity $\left(i_{\mathrm{p}} / c_{\mathrm{EP}}\right)$ of the prepared sensor for epinephrine determination was determined as $2.83 \mathrm{~A} \mathrm{~cm}^{-2}$ $\mathbf{M}^{-1}$. Moreover, the detection limit (it should be emphasized that the lower value of the detection limit means the possibility of the detection of the lower analyte concentration) of epinephrine was estimated as $0.0074 \mu \mathrm{M}$ according to the formula recommended by IUPAC: $c_{\mathrm{L}}=k \times s_{\mathrm{b}} / S$ (ref. 56) (where $s_{\mathrm{b}}$ is the standard deviation of the current density recorded in the supporting electrolyte solution evaluated on the basis of 10 times repeated measurements, $S$ is the slope of the linear $i_{\mathrm{p}} v s$. $c_{\mathrm{EP}}$ dependence and $k=3$ is a numerical constant).

One might also consider the effect of other interfering substances in the biological media. In the previous work ${ }^{36}$ we showed that both uric and ascorbic acids are effectively separated from dopamine when measured with $\mathrm{Mn} / \mathrm{Au}$ composite electrode. Herein, Fe/Au composite was experimentally proved to be capable of measuring the concentration of epinephrine in the presence of AA. The common feature of both composite systems is that their sensing-like properties are dependent on the electrostatic interactions, therefore the acidity of detected compounds determines the potential values at which they are detected. Per analogy, one might expect that $\mathrm{p} K_{\mathrm{a}}=4.1$ and $\mathrm{p} K_{\mathrm{a}}=$ 5.4 values of ascorbic and uric acids are amenable for the successive separation of the latter ones from EP herein as well. One might consider though if dopamine (DA) and epinephrine - which belong to the same family - could be effectively separated i.e. that the former one would not hinder the detection of the latter one. Oxidation of both compounds at the bare gold electrode happens at $E=0.27 \mathrm{~V} / \mathrm{SCE}$ (DA) and $E=0.31 \mathrm{~V} / \mathrm{SCE}$ (EP) respectively, alas the value of the peak separation $\left(\Delta E_{\mathrm{DA}-\mathrm{EP}}\right)$ is marginal. However, $\mathrm{p} K_{\mathrm{a}}$ values of DA and EP are 8.74 (ref. 57) and 9.90 (ref. 58) respectively. This means that both molecules would be present in their cationic form and would be positively attracted to the (1)/Au composite electrode. The most important however is that over an order of magnitude difference in acidity between EP and DA is enough for their effective separation to occur, hence EP can be successfully sensed in the presence of either AA, UA or DA.

The results observed prove that the modified gold electrode enhances the sensitivity towards EP detection since at the bare gold the linearity between the current density and the EP concentration was obtained in a narrower concentration range (0.1 $\mu \mathrm{M}$ to $500 \mu \mathrm{M}$ ) with the detection limit $c_{\mathrm{L}}=0.13 \mu \mathrm{M} \cdot{ }^{31}$ Moreover, it is worth noting that both the range of concentrations over which the EP content can be reliably estimated on the basis of the above regression equation and the EP detection limit is comparable or even higher than those reported in some literature for different modified electrodes (for comparison see ref. 59). It should be however noted that the data presented in Table 1 from ESI $\dagger$ of ref. 59 are estimated to EP behavior in water solution, but as determination is made in vitro condition the replacement of water by ACN will have no effect on such a comparison.

\subsection{Electrode reproducibility and stability of the modified electrode}

In the reproducibility tests, it was found that the relative standard deviations (RDS) of ten replicate voltammetric responses of $500 \mu \mathrm{M}$ epinephrine solution on the novel $\mathrm{Au} / \mathrm{Fe}$-complex SAM modified gold electrode was less than 3\% indicating excellent reproducibility of the prepared sensor. The stability of the $\left[\mathrm{Fe}_{2}\left(\mathrm{H}_{3} \mathrm{~L}\right)_{2}(\mathrm{MeOH})_{2}(\mu-\mathrm{OMe})_{2}\right]\left(\mathrm{ClO}_{4}\right)_{4}$ modified electrode was checked daily during two weeks. Before each subsequent measurement, the electrically active composite was only washed with ACN. In two weeks, the voltammetric responses for the 500 $\mu \mathrm{M}$ epinephrine solution decreased by about $5 \%$ of their initial response.

\section{Conclusions}

The results of the study demonstrate that the newly synthesized $\left[\mathrm{Fe}_{2}\left(\mathrm{H}_{3} \mathbf{L}\right)_{2}(\mathrm{MeOH})_{2}(\mu-\mathrm{OMe})_{2}\right]\left(\mathrm{ClO}_{4}\right)_{4}$ complex effectively forms SAMs on gold electrodes and exhibits valuable properties with respect to the electrochemical activity of epinephrine a compound of biological importance. We have shown that previously published, shielded, $\mu$-phenoxo bridged 'closed' architecture of $\left[\mathrm{Mn}_{2}\left(\mathrm{H}_{2} \mathbf{L}\right)_{2}\right]\left(\mathrm{ClO}_{4}\right)_{2}$ is not mandatory to form stable composites at gold electrode, as herein studied Fecomplex exhibits different conformation of $\mathrm{H}_{3} \mathbf{L}$ ligand and thus structure. This finds reflection in different adsorption mode at the gold surface, yet still retains its electrocatalytic properties and thus offers a new insight into electrochemical modification of gold. We have also isolated and characterized $\mathrm{H}_{3} \mathrm{~L}$ ligand and could thus demonstrate that not only complex 1 may be formed via direct reaction but also that the electrochemically mediated deposition of the sole ligand does not occur. It is crucial to note that present study paves the way towards design of a broader array of Schiff base metallosupramolecular architectures as electrochemical sensors towards neurotransmitters. The modified electrode shows good selectivity, sensitivity, reproducibility and high stability. There is no doubt that the modified electrode prepared in this paper is suitable for precise determination of EP concentration without any interference of AA. The prepared voltammetric sensor may be used - upon extraction of the analite from the real sample for in vitro determination of epinephrine, as it is not important if the EP in such analysis is prepared in water or in ACN. What is of significant notice is that utilization of our sensor does not cause ACN to be introduced into the human body. The preparation procedure of the modified electrode with the Fe-complex SAM is simple and has promising application for detection of EP in physiological environment. An explanation of the detailed mechanism of EP oxidation on the electrode modified with the $\left[\mathrm{Fe}_{2}\left(\mathrm{H}_{3} \mathbf{L}\right)_{2}(\mathrm{MeOH})_{2}(\mu-\mathrm{OMe})_{2}\right]\left(\mathrm{ClO}_{4}\right)_{4}$ complex, of its structure and interaction between obtained SAM layer and EP will be the task of our future study. Furthermore, isolation of $\mathrm{H}_{3} \mathrm{~L}$ ligand will allow us to synthesize new architectures that comprise other d-metal ions, when the template approach was not successful.

\section{Acknowledgements}

This research was carried out as a part of the Polish Ministry of Science and Higher Education project (Grant No. 0111/DIA/ 2012/41) in the frame of "Diamond Grant" programme. AG: I 
declare that I am a scholarship holder: (i) funded by the Polish National Science Center (Grant No. 2016/20/T/ST5/00187) in the frame of ETIUDA programme; (ii) within the project "Scholarship support for Ph.D. students specializing in majors strategic for Wielkopolska's development”, Sub-measure 8.2.2 Human Capital Operational Programme, co-financed by European Union under the European Social Fund as well as (iii) of The Adam Mickiewicz University Foundation in Poznań, 2014/2015 year edition. The Ministry of Scientific Research, Poland is gratefully acknowledged by T. Łuczak and K. Szymkowiak for financial support of this work.

\section{Notes and references}

1 K. E. Barrett, S. M. Barman, S. Boitano and H. L. Brooks, Ganong's review of medical physiology, McGraw-Hill e-Book, $24^{\text {th }}$ edn, 2012.

2 M. Mueller, Clinical pharmacology: current topics and case studies, Springer, Vienna, 2008.

3 M. D. Hawley, S. V. Tatawawadi, S. Piekarski and R. N. Adams, Electrochemical studies of the oxidation pathways of catecholamines, J. Am. Chem. Soc., 1967, 89, 447.

$4 \mathrm{~J}$. Chen and C. S. Cha, Detection of dopamine In the presence of a large excess of ascorbic acid by using the powder microelectrode technique, J. Electroanal. Chem., 1999, 463, 93.

5 W. Ren, H. Q. Luo and N. B. Li, Simultaneous voltammetric measurements of ascorbic acid, epinephrine and uric acid at a glassy carbon modified with caffeic acid, Biosens. Bioelectron., 2006, 21, 1086.

6 A. Salimi, C. E. Banks and R. G. Compton, Abrasive immobilization of carbon nanotubes on basal plane pyrrolytic graphite electrode: application to the detection of epinephrine, Analyst, 2004, 129, 225.

7 G. P. Jin, X. Peng and Y. F. Ding, The electrochemical modification of clenbuterol for paraffin-impregnated graphite electrode, Biosens. Bioelectron., 2008, 24, 1031.

8 F. C. Moraes, L. C. Golinelli, L. H. Mascaro and S. A. S. Machado, Determination of epinephrine in urine using multi-walled carbon nanotube modified with cobaltophtalocyanide in paraffin composite electrode, Sens. Actuators, B, 2010, 148, 492.

9 Y. Zeng, J. Yang and K. Wu, Electrochemistry and determination of epinephrine using a mesoporous Alincorporated $\mathrm{SiO}_{2}$ modified electrode, Electrochim. Acta, 2008, 53, 4615.

$10 \mathrm{X}$. Jiang and X. Lin, Immobilization of DNA on carbon fiber microelectrodes by using overoxidized polypyrrole template for selective detection of dopamine and epinephrine in the presence of high concentrations of ascorbic and uric acid, Analyst, 2005, 130, 391.

11 B. Jin and H. Zhang, Nano-gold modified glassy carbon electrode for selective determination of epinephrine in the presence of ascorbic acid, Anal. Lett., 2002, 35, 1907.

12 N. F. Atta, A. Galal and S. M. Azab, Electrochemical determination of neurotransmitters using gold nanoparticles on nafion/carbon paste modified electrode, $J$. Electrochem. Soc., 2012, 159, H765.

13 N. F. Atta, A. Galal, F. M. Abu-Attia and S. M. Azab, Simultaneous determination of paracetamol and neurotransmitters in biological fluids using a carbon paste sensor modified with gold nanoparticles, J. Mater. Chem., 2011, 21, 13015.

$14 \mathrm{~J}$. Li and X. Q. Lin, Electrodeposition of gold nanoclusters on overoxidized polypyrrole film modified glassy carbon electrode and its application for the simultaneous determination of epinephrine and uric acid under coexistence of ascorbic acid, Anal. Chim. Acta, 2007, 596, 222.

15 Y. Zhang, W. Ren and S. Zhang, Simultaneous determination of epinephrine, dopamine, ascorbic acid and uric acid by poly dopamine-nanogold composites modified electrode, Int. J. Electrochem. Sci., 2013, 8, 6839.

16 W. Ren, H. Q. Luo and N. B. Li, Simultaneous voltammetric measurements of ascorbic acid, epinephrine and uric acid at a glassy carbon modified with caffeic acid, Biosens. Bioelectron., 2006, 21, 1086-1092.

17 S. M. Chen and K. C. Lin, The electrocatalytic properties of biological molecules using polymerized luminal filmmodified electrodes, J. Electroanal. Chem., 2002, 523, 93.

18 F. Ni, Y. Wang, D. Zhang, F. Gao and M. Li, Electrochemical oxidation of epinephrine and uric acid at a layered double hydroxide film modified glassy carbon electrode and its application, Electroanalysis, 2009, 22, 1130.

19 P. Kalimuthu and S. A. John, Simultaneous determination of epinephrine, uric acid and xanthine in the presence of ascorbic acid using an ultrathin film of 5-amino-1,3,4thiadiazole modified electrode, Anal. Chim. Acta, 2009, 647, 97.

20 G. P. Jin, Q. Z. Chen, Y. F. Ding and J. B. He, Electrochemistry behaviour of adrenalin, serotonin and ascorbic acid at novel poly rutin modified paraffin-impregnated graphite electrode, Electrochim. Acta, 2007, 52, 2535.

21 Z. Yang, G. Hu, X. Chen, J. Zhao and G. Zhao, The nano-Au self assembled glassy carbon electrode for selective determination of epinephrine in the presence of ascorbic acid, Colloids Surf., B, 2007, 54, 230.

22 J. A Ni, H. X. Ju, H. Y. Chen and D. Leech, Amperometric determination of epinephrine with an osmium complex and Nafion double-layer membrane modified electrode, Anal. Chim. Acta, 1999, 378, 151.

23 S. M. Chen and K. T. Peng, The electrochemical properties of dopamine, epinephrine, norepinephrine and their electrocatalytic reactions on cobalt(II) hexacyanoferrate films, J. Electroanal. Chem., 2003, 547, 179.

24 S. M. Chen and C. J. Liao, Preparation and characterization of osmium hexacyanoferrate films and their electrocatalytic properties, Electrochim. Acta, 2004, 50, 115.

25 S. M. Chen, C. J. Liao and V. S. Vasantha, Preparation and electrocatalytic properties of osmium oxide/ hexacyanoruthenate films modified electrodes for catecholamines and sulphur oxoanions, J. Electroanal. Chem., 2006, 589, 15. 
26 A. Ulman, Formation and structure of self-assembled monolayers, Chem. Rev., 1996, 96, 1533.

27 Ž. Petrović, M. Metikoš-Huković and R. Babić, Potentialassisted assembly of 1-dodecanethiol on polycrystalline gold, J. Electroanal. Chem., 2008, 623, 54.

28 S.-F. Wang, D. Du and Q.-C. Zou, Electrochemical behaviour of epinephrine at L-cysteine self-assembled monolayers modified gold electrode, Talanta, 2002, 57, 687.

29 H.-M. Zhang, X.-L. Zhou, R.-T. Hui, N.-Q. Li and D.-P. Liu, Studies of the electrochemical behavior of epinephrine at a homocysteine self-assembled electrode, Talanta, 2002, 56, 1081.

30 N. F. Atta, A. Galal and E. H. El-Ads, A novel sensor of cysteine self-assembled monolayers over gold nanoparticles for the selective determination of epinephrine in presence of sodium dodecyl sulphate, Analyst, 2012, 137, 2658.

$31 \mathrm{~T}$. Łuczak, Comparison of electrochemical oxidation of epinephrine in the presence of interfering ascorbic and uric acids on gold electrodes modified with Sfunctionalized compounds and gold nanoparticles, Electrochim. Acta, 2009, 54, 5863.

32 T. Łuczak, Gold electrode modified with self-assembled layers made of sulphur compounds and gold nanoparticles used for selective electrocatalytic oxidation of catecholamine in the presence of interfering ascorbic and uric acid, Int. J. Electrochem., 2011, 1.

$33 \mathrm{~T}$. Łuczak, Epinephrine oxidation in the presence of interfering molecules on gold and gold electrodes modified with gold nanoparticles and thiodipropionic acid in aqueous solution. A comparative study, Electroanalysis, 2009, 21, 2557.

34 A. Gorczyński, M. Kubicki, D. Pinkowicz, R. Pełka, V. Patroniak and R. Podgajny, The first example of erbium triple-stranded helicates displaying SMM behavior, Dalton Trans., 2015, 16833.

35 A. Gorczyński, M. Zaranek, S. Witomska, A. Bocian, A. R. Stefankiewicz, M. Kubicki, V. Patroniak and P. Pawluć, The cobalt(II) complex of a new tridentate Schiffbase ligand as a catalyst for hydrosilylation of olefins, Catal. Commun., 2016, 78, 71.

36 A. Gorczyński, D. Pakulski, M. Szymańska, M. Kubicki, K. Bułat, T. Łuczak and V. Patroniak, Electrochemical deposition of the new manganese(II) Schiff-base complex on a gold template and its application for dopamine sensing in the presence of interfering biogenic compounds, Talanta, 2016, 149, 347.

37 M. Sajid, M. K. Nazal, M. Mansha, A. Alsharaa, S. M. S. Jillani and C. Basheer, Chemically modified electrodes for electrochemical detection of dopamine in the presence of uric acid and ascorbic acid: a review, Trends Anal. Chem., 2016, 76, 15.

38 Agilent Technologies, CrysAlis PRO (Version 1.171.33.36d), Agilent Technologies Ltd, 2011.

39 A. Altomare, G. Cascarano, C. Giacovazzo and A. Gualardi, Completion and refinement of crystal structures with SIR92, J. Appl. Crystallogr., 1993, 26, 343.
40 G. M. Sheldrick, A short history of SHELX, Acta Crystallogr., Sect. A: Found. Crystallogr., 2008, 64, 112.

41 A. L. Spek, PLATON SQUEEZE: a tool for the calculation of the disordered solvent contribution to the calculated structure factors, Acta Crystallogr., Sect. C: Struct. Chem., 2015, 71, 9.

42 T. Łuczak, A comparative studies of adsorption of aliphatic amines at a polycrystalline gold electrode, Collect. Czech. Chem. Commun., 2005, 70, 2027.

$43 \mathrm{~J}$. Nitschke, Construction, substitution and sorting of metallo-organic structures via subcomponent selfassembly, Acc. Chem. Res., 2007, 40, 103.

44 D. W. Mulder, E. M. Shepard, J. E. Meuser, N. Joshi, P. W. King, M. C. Posewitz, J. B. Broderick and J. W. Peters, Insights into [FeFe]-hydrogenase structure, mechanism and maturation, Structure, 2011, 19, 1038.

$45 \mathrm{~J}$. J. Griese, V. Srinivas and M. Högbom, Assembly of nonheme $\mathrm{Mn} / \mathrm{Fe}$ active sites in heterodinuclear metalloproteins, JBIC, J. Biol. Inorg. Chem., 2014, 19, 759.

$46 \mathrm{H}$. Houjou, M. Kanesato, K. Hiratani and D. Mandon, Structural and electrochemical studies of novel bis $(\mathrm{m}-$ methoxo)diiron complexes: observation of FeIIIFeIV and FeIVFeIV states resonating with phenoxyl radicals, Chem.Eur. J., 2004, 10, 4576.

47 S. Alvarez, P. Alemany, D. Casanova, J. Cirera, M. Llunell and D. Avnir, Shape Maps and Polyhedral Interconversion Paths in Transition Metal Chemistry, Coord. Chem. Rev., 2005, 249, 1693.

48 M. Llunell, D. Casanova, J. Cirera, P. Alemany and S. Alvarez, Shape v. 2.0, Universitat de Barcelona, Barcelona, 2010.

49 A. Bielański, Inorganic Chemistry, PWN, Warsaw, 1999.

50 J. McMurry, Organic Chemistry, National Scientific Publishers, Warsaw, 2005.

51 G. Dodero, L. De Michieli, O. Cavalleri, R. Rolandi, L. Olivieri, A. Dacca and R. Parodi, L-Cysteine chemisorption on gold: an XPS and STM study, Colloids Surf., A, 2000, 175, 121.

52 A. J. Bard and L. K. Faulkner, Electrochemical methods: Fundamentals and Applications, Wiley, New York, 2001.

53 T. Łuczak, Electrocatalytic application of an overoxidized dopamine film prepared on a gold electrode surface for selective epinephrine sensing, Electroanalysis, 2008, 20, 1317.

54 I. Kaljurand, A. Kutt, L. Soovali, T. Rodima, V. Maemets, I. Leito and I. A. Koppel, Extension of the self-consistent spectrophotometric basicity scale in acetonitrile to a full span of $28 \mathrm{p} K_{\mathrm{a}}$ units: unification of different basicity scales, J. Org. Chem., 2005, 70, 1019.

55 A. Kutt, I. Leito, I. Kaljurand, L. Soovali, V. M. Vlasov, L. M. Yagupolskii and I. A. Koppel, A comprehensive selfconsistent spectrophotometric acidity scale of neutral Brønsted acids in acetonitrile, J. Org. Chem., 2006, 71, 2829.

56 Analytical Methods Committee, Recommendation for definition, estimation and use of the detection limit, Analyst, 1987, 112, 199.

57 B. J. F. Hill and D. C. Dyer, Pharmacological characterization of $\alpha$-adrenoceptors in the bovine median caudal artery, Eur. J. Pharmacol., 1997, 339, 147. 
58 E. Dempsey, A. Kennedy, N. Fay and T. McCormac, Investigations into heteropolyanions as electrocatalysts for the oxidation of adrenaline, Electroanalysis, 2003, 15, 1835.

59 T. Łuczak, M. Bełtowska-Brzezinska and R. Holze, Electrocatalytic activity of gold modified with gold nanoparticles and self-assembled layers of meso-2,3dimercaptosuccinic acid for oxidation of epinephrine in the presence of ascorbic and uric acid, Electrochim. Acta, 2014, 123, 135. 